\title{
Discussion on the Relationship Between Characteristics of Self-Service Restaurants and Consumption Willingness
}

\author{
Shwu-Ing $\mathrm{Wu}^{1} \&$ Zhen-Yi $\mathrm{Ji}^{1}$ \\ ${ }^{1}$ Department of Business Administration, National Chin-Yi University of Technology, Taiwan \\ Correspondence: Shwu-Ing Wu, Department of Business Administration, National Chin-Yi University of Technology, \\ No.57, Section 2, Zhongshan Road, Taiping, Taichung, Taiwan. Tel: 886-4-2392-4505.
}

Received: January 7, 2019

Accepted: January 27, 2019

Online Published: January 30, 2019

doi:10.5430/jms.v10n1p13

URL: https://doi.org/10.5430/jms.v10n1p13

\begin{abstract}
Since changed in external environment and technology as well as diversified demands of customers, the innovation of dishes and services is necessary to attract customers. Therefore, based on literature analysis and empirical research, this study discussed the relationship among customers' experience connotation to self-service restaurants, service characteristics, customers' technology involvement, attractions of self-service restaurants, customers' perceived values and customers' consumption willingness; and further compared the difference on the relationship mode between the groups who are and are not willing to spend money at self-service restaurants.

In this study, the consumers who were 15 or above in Taiwan and had eating-out experience were taken as the main respondents and the questionnaires were sent by staff to carry out the convenient sampling survey, and totally, 650 valid questionnaires were collected. Then, the consumers were divided into two groups: the group with certain consumption intentions and the group with uncertain consumption intentions, according to the condition whether they will be willing to spend money at self-service restaurants in the future, in order to conduct group pattern comparison. It is found from the results that the two groups are significantly different in the strength of the 3 relationship paths. Therein: (1) the customers' technology involvement of the group with certain consumption intentions has significantly positive effects on the paths to the customers' perceived values and is stronger than that of the group with uncertain consumption intentions, (2) the attractions of self-service restaurants to the group with certain consumption intentions have significantly positive effects on the paths to the customers' perceived values and is stronger than that to the group with uncertain consumption intentions, (3) the customers' perceived values of the group with certain consumption intentions have significantly positive effects on the paths to the customers' consumption willingness and is stronger than that of the group with uncertain consumption intentions. From the study results, the consumption willingness models of both groups are also different. The results can be provided to the operators of self-service restaurants as the reference to make decisions.
\end{abstract}

Keywords: self-service restaurant, technology involvement, consumption willingness

\section{Introduction}

In recent years, the catering industry is developing day by day. According to the analysis made by the Ministry of Economic Affairs and the Department of Accounting and Statistics of Executive Yuan (2018), the annual growth rate of the business volume in the catering industry increases 5.2\%, and the average amount of "eating out costs" for each family increases year by year. The proportion of the Taiwanese people who eat out at least one day per week exceeds $70 \%$, with more than half of the times for eating out each week, which shows that the Taiwanese people eat out at a very high rate and thus brings immense business opportunities (Unilever Food Solutions, 2012).

However, customers' demands will continually change with changing times, and the catering industry which contacts highly with people is no exception. Chanaka et al. (2007) believed that, in the service delivery process, the close interaction between service providers and customers is involved and will certainly affect the customers' evaluation results. Lovelock \& Young (1979) indicated that one effective way for the enterprises to increase profits is to let the consumers complete more actions, namely self-service. In recent years, due to technological advances, the consumers can easily take operations to obtain services, for instance, the most common automatic teller machines and online shopping both provide self-service. Kay (1993) believed that, the science and technology orientation can be used to enhance the production yield and effectively meet individual customers' demands, and thus bring more 
convenient and diversified experience to the consumers. In this way, the attractions can be improved and the traditional views of the catering industry can be broken through, and furthermore, the competitiveness will be promoted.

In recent years, the sales methods are changed gradually from the original store sales to the subsequent self-service stores, and the transaction way of vending machines even derived. These ways are all out of the consideration of the solutions on human costs. In 2003, am/pm, a Japanese supermarket chain, and Nichimen, a Japanese company, jointly initiated the "self-service convenient supermarket", providing the unmanned self-service transaction mode. In 2005, self-service stores also arose in Taiwan. For instance, CPC Corporation, Taiwan adopted the self-service business model to cultivate the market of "self-service gas stations". In July 2017, Alibaba, the leading e-commerce company in China, launched the unmanned concept store "Taocafe". In January 2018, Amazon Go officially opened the unmanned store "Amazon Go" to the public, in the unmanned store, the commodities can be taken without assistance from the cashiers and the deduction and checkout can be conducted through the automatic human face recognition. Meanwhile, 7-ELEVEN, the leading convenient supermarket in Taiwan, also launched "X-Store unmanned smart store". In the concept store, in addition to the human face recognition used for the customers to go in and out the store, the automated equipment such as automatic induction refrigerator, electronic label identification, self-service check-out scanning and scanning microwave oven are equipped in the outlet, and the checkout is completed with the icash 2.0 cards by setting the Open Point on APP, indicating that unmanned stores are the future trend. The "self-service restaurants" appear after the concept of unmanned store is applied into the restaurants. The operators bring in the self-service technology to replace service staff, which can reduce routine tasks of the service staff, decrease the process of service delivery and save large amount of personnel costs for the operators (Lee \& Allway, 2002). The wave of unmanned store has been gradually launched all around the world. Regarding the catering industry, there is currently no fully-automated operation mode, but only some dealers operate in the similar mode. For instance, Sushi Express Group and Hi Sushi in Taiwan, Baggers in Germany and K\&L 98 Hot pot n' Grill in the United States all provide services with a few service staff accompanied with machinery equipment to reduce human costs. Hence, the feasibility of self-service restaurant is worthy to be discussed.

People's dietary habits are not just stuck with products and services as in the past but more focused on the immersive experience provided by the enterprises, which affect consumers' cognition and emotional interaction and become the core of the consuming behaviors (Arnold, Price \& Zinkhan, 2004). Furthermore, innovation is an important element to attract people to experience. Den Hertog \& Bliderbeek (1999) presented the four dimensions of service innovation, which are respectively the new service concept, new customer interface, new service delivery system and technological options, hoping the various forms of innovation can be brought in to attract consumers. Moreover, the innovation in information technology provides a new tool for the catering industry, and based on the radio frequency identification (RFID), the interactive customer service is carried out and the consumer preference database is established to increase the service quality and efficiency (Hozak, 2012). The consumers' willingness strength in using innovative services will be affected by the way of providing innovative services and their level of involvement, for the perceived ease of use and the perceived usefulness will also indirectly affect the usage willingness and the usage behavior through the usage attitude (Fishbein \& Ajzen, 1975; Davis, 1989; Ajzen, 1991), indicating that the level of technology involvement will also affect people's acceptance to the new technology service modes.

As seen above, customer experience, service innovation and technology application are the key items in the future catering service industry. Hence, this study took the self-service restaurants as the example to discuss the relationship between the self-service restaurants' operation characteristics and the consumers' consumption willingness, and took the public's experience connotation to the self-service restaurants, overall service characteristics and technology involvement as the independent variables to discuss its effects on the attractions, customers' perceived values and consumption willingness of self-service restaurants, in order to understand the possibility and development potential of self-service restaurants, furthermore conducts comparative analysis on the groups who are and are not willing to spend money at self-service restaurants to discuss the differences.

\section{Literature Review and Research Hypotheses}

\subsection{Effects of Experience Connotation to Self-Service Restaurants on Attractions}

Since the experience economy era came in the end of the $20^{\text {th }}$ century, the marketing emphasis has turned into "creating valuable experience". As a result, the enterprises perform differentiated marketing strategies by providing consumers with good, unique and profound experience to facilitate the customers to enjoy the new wave of commodities and fashion (Sproles, 1985). Consequently, "experience" has become the key factor to analyze consuming behaviors (Pine \& Gilmore, 1998; Addis \& Holbrook, 2001). In the creative idea on future restaurants, 
the consumer demands and the shopping convenience of stores can be used as the major appeals, and RFID can be employed to combine living technology and future retailing modes. For instance, as for the outlets equipped with RFID electronic labels, the systems will automatically transfer the information to the backend order processing systems, and then the employees will be timely reminded to re-check the goods and adjust and distribute items on shelves, in order to provide the consumers with shopping convenience and brand-new consumption experience and establish the human-computer interaction programs (Horng, 2015). Hence, fashion, uniqueness and creativity are the important items to measure the experience connotation.

People take part in various activities in their spare time to pursue or enjoy freedom and pleasure and hope to achieve personal satisfaction, and these positive experience and feelings are the origins of attractions (Fennell, 2002). When the consumers contact with products or services, the acquired experience will produce different attractions depending on whether the results meet their own demands (Bake \& Crompton, 2000). As a result, the consumers' experience with some products or consumption situations will affect the attractions of the products or service. This study applied the above arguments in the self-service restaurants and presented the following hypothesis:

H1: "Experience connotation" to self-service restaurants would have significant positive influence on the "attractions"

\subsection{Effects of Experience Connotation to Self-Service Restaurants on Consumers' Perceived Values}

The experience may be produced at the moment when the products or services are provided, to meet the consumers' current requirements and then produce the positive perceived values (Schmitt, 2000; Pine \& Gilmore, 2003). Schmitt (1999) presented the experiential marketing strategy module to discuss the relationship between experience and perceived values for the consumers, and the results show that the consumers' benefits and pays in consumption will affect their perceived values due to the experience in the consumption process (Norris, 1941; Holbrook, 1999; Monroe, 1990). Hence, the consumers will produce perceived values through the experience media and raise the final consuming behaviors (Sheth, 1991; Schmitt, 1999). After stimulated by experience, the consumers will produce the subjective perceived values in their minds to judge the quality of commodity or service, and further affect the consumers' decisions (Holbrook, 1999). Based on the above, this study presented the following hypothesis:

H2: "Experience connotation" to self-service restaurants would have significant positive influence on consumers' "perceived values"

\subsection{Effects of Service Characteristics of Self-Service Restaurants on Attractions}

The most typical method to measure the service quality is the "SERVQUA scale" proposed by 3 scholars who are Parasuraman \& Zeithaml \& Berry (1985), including 5 measurement dimensions, respectively: (1) tangibility: for example, the self-service restaurants need to be equipped with physical facilities, tools and equipment; (2) reliability: for example, certain quality services can be enjoyed in the self-service restaurants; (3) responsiveness: for example, just-in-time services and quick responds can be enjoyed in the self-service restaurants, if machines cannot satisfy the customers' demands, staff are required to offer assistance; (4) assurance: for example, when the equipment is operated in the self-service restaurants, people's operation will not be impeded and thus affect the usage willingness; (5) empathy: for example, the paths to convey customer comments can be provided in the self-service restaurants. As a result, this study integrated the views of Parasuraman \& Zeithaml \& Berry (1985) and the service characteristics of self-service restaurants, and took the 5 dimensions such as tangibility, reliability, responsiveness, assurance and empathy as the items for the consumers' to measure the service characteristics of self-service restaurants.

Moreover, services are the key part in value chain to create profits, and the restaurants with higher service quality will normally make the consumers feel they are more attractive (Heskett, Jones, Loveman, Sasser \& Schlesinger, 1994). During the contact between customers and service providers, the more the service characteristics can satisfy the consumers' demands, the more the customers will be attracted (Lehtinen \& Lehtinen, 1982; Leiper, 1990). Hence, this study inferred the following hypothesis:

H3: "Service characteristics" of self-service restaurants would have significant positive influence on the "attractions"

\subsection{Effects of Service Characteristics of Self-Service Restaurants on Consumers'Perceived Values}

In the process of consumption, the customers will form the feelings of perceived values according to various service items. With higher service quality, the customers' level of perceived values will be higher, on the contrary, with lower service quality, the customers' level of perceived values will be lower (Cronin \& Taylor , 1992). Hence, consumers will consider services as the antecedent variables of perceived values. Only the service requirements are highly met, 
the consumers' judgment on perceived values will be directly and positively improved (Gronroos, 1984). The same service items are not only the customers' requirements on restaurants but also the origins of the perceived values produced by the customers after the services are accepted (Zeithaml, 1988). After accepting products or services, the consumers will have evaluations on perceived values. The more the service can satisfy the consumers' requirements, the more positive the perceived values will be (Lovelock, 2001). On this basis, this study inferred the following hypothesis:

H4: "Service characteristics" of self-service restaurants would have significant positive influence on consumers' "perceived values"

\subsection{Effects of Consumers' Technology Involvement on the "Attractions" of Self-Service Restaurants}

Involvement refers that individual persons have different attentions and associations on different things (McIntyre \& Pigram, 1992). By integration of the concept of technology and involvement, the technology involvement can be considered as "the consumers' attentions and concerns on the subject matters of technology". The issue whether the consumers can accept the innovative services can be discussed with the dimensions proposed by Davis (1989) in the technology acceptance model (TAM): (1) Perceived usefulness: the usefulness will affect the users' acceptance of technology systems indirectly through attitudes or directly, hence, the perceived usefulness will enhance the involvement, (2) Perceived ease of use: people believe that if certain systems can be used without any physical or mental efforts, then the involvement will be higher, indicating that those who use technology products related to $3 \mathrm{C}$ at ordinary times can easily operate the self-service restaurants. For people are increasingly dependent on technology, in order to closely contact with customers, the enterprises must increase the services that the customers want in technology applications to make the relationship between technology and people's life inseparable (Evans \& Laskin, 1994). As a result, the effects of technology involvement on people's life are worthier to be discussed.

In addition, if continuously involved in something, the consumers will produce the feeling of attraction for relevant activities (McIntyre, 1989; McIntyre \& Pigram, 1992). It is can be seen that, for self-service restaurants, the consumers also can produce the cognition of attraction to the restaurants due to technology involvement (Kyle \& Mowen, 2005). On this basis, this study inferred the following hypothesis:

H5: Consumers' "technology involvement" would have significant positive influence on "attractions" of self-service restaurants

\subsection{Effects of Consumers' Technology Involvement on Consumers' Perceived Values}

Consumers' different involvement in products or services will generate different perceived values to products or services, and the subsequent decisions and behaviors will be different (Schiffman \& Kanuk, 2000; Blackwell et al., 2001; Hanna \& Wozniak, 2001). Belanche, Flavián, \& Alfredo (2016) defined the involvement in products or services as the consumers' value cognitions on importance of products or services, depending on the inherent demands, values and interests in products or services, just as the consumers have different acceptance to the changes in consumption patterns due to different technology involvement in self-service restaurants. If the consumers put great mental efforts and pay lasting attentions, they will feel the values brought by products. Therefore, higher technology involvement indicates higher perceived values to self-service restaurants, and consumers will be willing to invest in relevant consumptions (Laurent \& Kapferer, 1985). On this basis, this study inferred the following hypothesis:

H6: Consumers' "technology involvement" would have significant positive influence on consumers' "perceived values"

\subsection{Effects of “Attractions" of Self-Service Restaurants on Consumers' Perceived Values}

Cong et al. (2008) indicated that themed restaurants create a unique atmosphere and provide services and dinners in a pleasant way to enable the consumers to feel the restaurants' attractions, such as environment, design, theme, to seize the hearts of consumers. This study formulated the attractions of self-service restaurants for five items: creation, facilities, services, themes and participation, to measure the consumers' views on the attractions of self-service restaurants.

The attractions refer to the consumers' evaluations on various options in the market, and the perceived values will be produced by measuring the satisfaction of the demands (Jones, Motherbaugh \& Beatty, 2000). Hence, the consumers will form their value cognitions if feeling the attractions of self-service restaurants, such as themes, facilities and services of restaurants. If the consumers feel the attractions, their perceived values, consumption behaviors and intentions will be improved (Bolton \& Drew, 1991; Lovelock, 2001; Kwun \& Oh, 2004). On this basis, this study 
inferred the following hypothesis:

H7: "Attractions" of self-service restaurants would have significant positive influence on consumers' "perceived values"

\subsection{Effects of "Attractions" of Self-Service Restaurants on Consumption Willingness}

Morwitz \& Schmittlein (1992) believed that the consumption willingness is the consumers' evaluations and opinions on products and will enable the consumers to generate actual purchasing actions. Fishbein \& Ajzen (1975) believed that, it is difficult to verify and trace the consumers' actual behaviors (for instance, intending to try or willing to spend money or recommending to others) in consumption situations, but only the willingness of certain behaviors can be predicted. The consumption willingness can be measured with 3 items: intending to try, willing to spend money, recommending to others.

The attractions are to measure the attractive strength of a subject matter, and the internal driving power can positively affect the consumers' consumption willingness (Leiper, 1990). Peter \& Weiermair (2000) believed that, based on relevant management methods and creativity by combining with the strategies and methods to attract the consumers, the attractions can be created and the consumption willingness will be promoted. For example, regarding self-service restaurants, the consumers will feel the attractions and produce the consumption willingness due to innovative services and unique facilities. Moreover, as the attractions increase, the consumers' willingness will be enhanced, which is the optimal index to predict the future consumption of consumers. On this basis, this study inferred the following hypothesis:

H8: "Attractions" of self-service restaurants would have significant positive influence on consumption willingness

\subsection{Effects of Consumers' Perceived Values on Consumption Willingness}

The perceived values will affect the consumers' impressions on products, while the values provided by products will affect the consumers' consumption willingness (Hulten, 2011). Hence, if the higher any product or service makes the consumers believe the value is, it indicates that the higher the perceived value of this product or service is, which will positively affect the consumers' consumption willingness for this product or service (Dodds, Monroe \& Grewal, 1991). It was pointed out in the past that the consumers' perceived values of casual restaurants have positive effects on the consumption willingness (such as, recommending to others, improving visit frequency) (Ryu et al., 2010). Therefore, the consumers' perceived values will affect the consumption willingness (Cronin, Brady \& Hult, 2000). Based on above, this study inferred the following hypothesis:

H9: Consumers" "perceived values" of self-service restaurants would have significant positive influence on consumption willingness

\subsection{Effects of Consumers' Consumption Willingness on the Relationship Modes of Self-Service Restaurants}

Berger (1979) believed that, when facing self-service restaurants, the consumers will be motivated to understand them. Under this condition, information searching behaviors will be promoted to be increased, and thus the two types of certain consumption willingness and uncertain consumption willingness will be produced. When the consumers trust the self-service restaurants, the novel consumption models based on technology involvement will enable the consumers to interact and cooperate with the self-service restaurants and improve the exchange willingness and frequency. The more certainly the group consumes, the higher the produced consumption willingness will be (Gefen, 2000; Chiu et al., 2006); otherwise, the group with more uncertain consumption intentions will produce differentiated cognitions due to selections on personal values (Lazarus \& Folkman, 1984). On this basis, the following hypothesis is proposed:

H10: Groups with different consumption willingness are significantly differentiated in the path strength of relationship models of self-service restaurants

\section{Research Design and Data Analysis}

\subsection{Research Framework}

In conclusion, this study discussed the effects of experience connotation, service characteristics and technology involvement on the attractions of self-service restaurants, consumers' perceived values and consumption willingness, and the relationship model paths of groups with different consumption willingness in self-service restaurants and the differentiation in relationship strength (see Figure 1). 




Figure 1. Research framework

\subsection{Sample Structure}

In this study, the consumers who had eating-out experience were taken as the study subjects and 700 questionnaires were sent by staff to carry out the convenient sampling survey. After 50 invalid questionnaires were excluded, the valid questionnaires were 650 , and the recovery rate was $92.9 \%$. By analysis on the recovered samples, it is learnt that, in terms of personal information, based on gender, women account for the largest proportion of $55.4 \%$, and the next is men, accounting for 44.6\%; based on age, those who aged between 25 and 34 account for the largest proportion of $38.3 \%$, and the next is those who aged between 15 and 24, accounting for $36.0 \%$; based on living areas, those who live in the southeast region and offshore islands account for the largest proportion of $41.3 \%$, the next is those who live in the north region, accounting for 30.9\%; based on education backgrounds, those who have the university (college) degrees account for the largest proportion of $75.5 \%$, the next is those who have the postgraduate degrees (master's degrees, doctorates) or above, accounting for 11.5\%; based on occupations, those who are freelancers account for the largest proportion of $29.5 \%$, the next is students, accounting for $26.5 \%$; those who have the average monthly income of NTD 10,001-30,000 account for the largest proportion of 46.8\%, the next is those who have the average monthly income of below NTD 10,000, accounting for $36.2 \%$.

\subsection{Reliability and Validity Analysis of Formal Survey}

In order to guarantee the questionnaire reliability and validity, this study conducted the reliability and validity analysis on 650 valid questionnaires. In this study, the questionnaire reliability and validity are evaluated with the Cronbach's $\alpha$ value and exploratory factor analysis. According to Nunnally (1978), if the Cronbach's $\alpha$ value is greater than 0.7, it indicates the high internal consistency which can be called as high reliability. Kerlinger (1978) proposed that the correlation coefficient of item to total is required to meet the decision criteria of being greater than 0.5. This study results show that the Cronbach's $\alpha$ value and correlation coefficients of all dimensions meet the criteria, as a result, the overall questionnaire reliability of this study is good (see Table 1).

As for validity analysis, the exploratory factor analysis (EFA) was used to verify the questionnaire convergent validity. The factors with the characteristic values greater than 1 are extracted by the principal component analysis. By the varimax rotation analysis, it is learnt that the variables under the 6 dimensions, such as experience connotation, service characteristic, technology involvement, attraction, perceived value and consumption willingness, can be classified into the same factors. The factor loadings of all variables in all the factors are larger than 0.5 , and the cumulative explained variances of all the factors are larger than 50\%, which indicates that all the questionnaire dimensions have the convergent validity (see Table 1).

This study evaluated the reliability and the validity based on the two indexes which are the composite reliability (CR) of latent variables and the average variance extracted (AVE) of latent variables. The decisions are made on the principle that the CR value is greater than 0.6 and the AVE value is greater than 0.5 (Fornell \& Larcker, 1981). The values of composite reliability (CR) of latent variables in all factors are between 0.8823 and 0.9278 and larger than 
0.6 , indicating that all the dimensions of this study have good internal consistency. The average variance extracted (AVE) of latent variables is ranged from 0.5097 to 0.6480 , which is larger than 0.5 and meets the ideal value, indicating that all the dimensions have the convergent validity (see Table 1).

Table 1 . Reliability and validity analysis of formal survey $(n=650)$

\begin{tabular}{|c|c|c|c|c|c|c|c|c|}
\hline Factors and items & Mean & $\begin{array}{l}\text { Item-to-total } \\
\text { correlation } \\
\text { coefficient }\end{array}$ & $\begin{array}{l}\text { Factor } \\
\text { loading }\end{array}$ & $\begin{array}{l}\text { Eigen } \\
\text { value }\end{array}$ & $\begin{array}{l}\text { Cumulative } \\
\text { explained } \\
\text { variation } \%\end{array}$ & $\begin{array}{l}\text { Cronbach } \\
\alpha \text { value }\end{array}$ & $\begin{array}{l}\text { Component } \\
\text { reliability } \\
(\mathrm{CR})\end{array}$ & $\begin{array}{l}\text { Average } \\
\text { variance } \\
\text { extracted } \\
\text { (AVE) }\end{array}$ \\
\hline \multicolumn{9}{|l|}{ Experience connotation } \\
\hline $\begin{array}{l}\text { The decoration design of } \\
\text { self-service restaurants } \\
\text { shall be in creative style. }\end{array}$ & 5.43 & .784 & .868 & \multirow{6}{*}{3.609} & \multirow{6}{*}{60.151} & \multirow{6}{*}{.866} & \multirow{6}{*}{0.9002} & \multirow{6}{*}{0.6017} \\
\hline $\begin{array}{l}\text { The catering equipment } \\
\text { offered in self-service } \\
\text { restaurants shall be } \\
\text { unique. }\end{array}$ & 5.31 & .682 & .792 & & & & & \\
\hline $\begin{array}{l}\text { The self-service } \\
\text { restaurants create the } \\
\text { styles different from } \\
\text { normal restaurants. }\end{array}$ & 5.55 & 676 & .787 & & & & & \\
\hline $\begin{array}{l}\text { The architectural } \\
\text { appearance of self-service } \\
\text { restaurants shall be in } \\
\text { special style. }\end{array}$ & 5.51 & .626 & .748 & & & & & \\
\hline $\begin{array}{l}\text { The food in self-service } \\
\text { restaurants shall be set } \\
\text { fashionably. }\end{array}$ & 5.19 & .624 & .743 & & & & & \\
\hline $\begin{array}{l}\text { The food names in } \\
\text { self-service restaurants } \\
\text { shall be creative. }\end{array}$ & 4.94 & .583 & .706 & & & & & \\
\hline \multicolumn{9}{|l|}{ Service characteristics } \\
\hline $\begin{array}{l}\text { The self-service } \\
\text { restaurants shall offer } \\
\text { meals properly. }\end{array}$ & 6.60 & .681 & .784 & \multirow{7}{*}{4.078} & \multirow{7}{*}{50.975} & \multirow{7}{*}{.861} & \multirow{7}{*}{0.892} & \multirow{7}{*}{0.5097} \\
\hline $\begin{array}{l}\text { The self-service } \\
\text { restaurants shall provide } \\
\text { clear and readable menus. }\end{array}$ & 6.58 & .657 & .779 & & & & & \\
\hline $\begin{array}{l}\text { The dishes in self-service } \\
\text { restaurants shall consistent } \\
\text { with the pictures in } \\
\text { menus. }\end{array}$ & 6.58 & .638 & .750 & & & & & \\
\hline $\begin{array}{l}\text { The self-service } \\
\text { restaurants shall enable } \\
\text { the consumers to feel } \\
\text { comfortable in operating } \\
\text { machines. }\end{array}$ & 6.45 & .632 & .743 & & & & & \\
\hline $\begin{array}{lr}\text { The } & \text { self-service } \\
\text { restaurants } & \text { shall have } \\
\text { clear } & \text { operation } \\
\text { instructions. } & \end{array}$ & 6.63 & .566 & .705 & & & & & \\
\hline $\begin{array}{l}\text { The self-service } \\
\text { restaurants shall provide } \\
\text { the customers with } \\
\text { complaint channels. }\end{array}$ & 6.45 & .578 & .684 & & & & & \\
\hline $\begin{array}{l}\text { The self-service } \\
\text { restaurants shall complete }\end{array}$ & 6.15 & .555 & 637 & & & & & \\
\hline
\end{tabular}


services at the promised

time.

The ordering machines in self-service restaurants shall correctly inform the consumers the delivery $6.06 \quad .523$ .609

time.

\section{Technology involvement}

I believe I can use the

$\begin{array}{llll}\text { systems of the self-service } & 5.82 & .716 & .809\end{array}$

restaurants on my own.

The ordering systems and instruments in self-service restaurants are easy to be $5.93 \quad .657$ operated.

I am not afraid of using new technological

products.

$\begin{array}{lll} & & \end{array}$

Automatic ordering

$6.14 \quad .633$

systems are the practical

$\begin{array}{ll}633 & .747\end{array}$

ordering way.

I like to order the food I want on my own.

$6.37 \quad .574 \quad .698$

I can accept to operate the instruments in self-service

$6.14 \quad .542$

restaurants on my own.

\begin{tabular}{llll}
$\begin{array}{l}\text { Self-service restaurants } \\
\text { are the future tendency. }\end{array}$ & 5.69 & .532 & .651 \\
\hline
\end{tabular}

\section{Attractions}

Free operation in self-service restaurants will be deeply attracted to $5.71 \quad .782$ .850

me.

The special facilities in


will be attractive to me.

The innovative consumption models in self-service restaurants

$5.83 \quad .738$

will be attractive to me.

The atmosphere of freedom in self-service restaurants will attract me

$5.70 \quad .738$

to spend money.

\begin{tabular}{llll}
\hline $\begin{array}{l}\text { The } \\
\text { restaurants } \begin{array}{c}\text { self-service } \\
\text { are the } \\
\text { particularly interesting }\end{array}\end{array}$ & 5.99 & .715 & .801 \\
ways of dining. & & \\
\hline $\begin{array}{l}\text { The ordering information } \\
\text { of self-service restaurants }\end{array}$ & 5.93 & .697 & .781 \\
is worth understanding. & & & \\
\hline $\begin{array}{l}\text { The unattended } \\
\text { environment } \quad \begin{array}{r}\text { of } \\
\text { self-service restaurants }\end{array}\end{array}$ & 5.44 & .643 & .730 \\
\end{tabular}

makes me relax.

\section{Consumers' perceived values}

\begin{tabular}{|c|c|c|c|c|c|c|c|c|}
\hline $\begin{array}{l}\text { The space of self-service } \\
\text { restaurants will be leisure. }\end{array}$ & 5.61 & .772 & .888 & 3.016 & 60.311 & .831 & 0.8823 & 0.6031 \\
\hline self-service & 5.72 & .715 & .851 & & & & & \\
\hline
\end{tabular}






\subsection{Confirmatory Factor Analysis}

In order to confirm the efficiency of measuring dimensions, this study carried out the confirmatory factor analysis (CFA) with AMOS software on the measurement models of six dimensions such as experience connotation to self-service restaurants, service characteristics of self-service restaurants, consumers' technology involvements, attractions of self-service restaurants, consumers' perceived values and consumers' consumption willingness. According to the model proposed by Carmines \& MacIver (1981), the fit indicators shall meet the ideal standard, thereinto, the ratio between Chi-square value and degree of freedom is no more than 3, RMSEA is less than 0.05 and the values of GFI, AGFI, NFI, RFI and CFI are greater than 0.9 (Bagozzi \& Yi, 1988; Joreskog \& Sorbom, 1989). The results show that, among the fit indicators of the measurement model, the value of $\chi^{2} / \mathrm{df}$ is 1.713 , the value of GFI is 0.915 , the value of AGFI is 0.9 , the value of NFI is 0.923 , the value of RFI is 0.914 , the value of CFI is 0.966 and the value of RMSEA is 0.033 , indicating that the fitness of all the measurement models reaches the acceptable range. Therefore, in this study, the fitness of the measurement model is good, representing that this measurement index has the construct validity and the measurement efficiency. 


\section{Analysis on Competing Model of Groups With Certain and Uncertain Consumption Willingness}

For 650 valid questionnaires collected, this study took the situations that people are certainly or uncertainly willing to spend money in self-service restaurants in the future as the block variables and divided the respondents into two groups. Totally, there are 498 questionnaires from the people who are certainly willing to spend money in self-service restaurants and 152 questionnaires from the people who are uncertainly willing to spend money in self-service restaurants.

In this study, the intergroup model comparison was conducted with AMOS software for the consumers who are certainly or uncertainly willing to spend money in self-service restaurants to discuss whether the consumers with different willingness have significant disturbing effects on the relationship between all dimensions and analyze the competition models. The results show that the value of $\chi^{2} / \mathrm{df}$ is 1.524 , the value of MRM is 0.063 , the value of GFI is 0.867 , the value of AGFI is 0.842 , the value of NFI is 0.873 , the value of RFI is 0.857 , the value of CFI is 0.952 and the value of RMSEA is 0.028 , which meet the principles of good models. Therefore, the fitness of the competition model in this study is good, indicating that this model is acceptable. The estimated values of the normalizing parameters in this competition model are analyzed as follows:

(1) The two groups have no significant difference (t=-0.381) in (H1) the effect strength of the experience connotation to self-service restaurants on the paths to the restaurants' attractions. In terms of effect coefficients, the groups with certain and uncertain consumption intentions both believe that the experience connotation to self-service restaurants will significantly affect the attractions of self-service restaurants.

(2) The two groups have no significant difference $(t=1.649)$ in $(\mathrm{H} 2)$ the effect strength of the experience connotation to self-service restaurants on the paths to the consumers' perceived values. In terms of effect coefficients, the groups with certain and uncertain consumption intentions both believe that the experience connotation to self-service restaurants will significantly affect the consumers' perceived values.

(3) The two groups have no significant difference $(t=1.151)$ in (H3) the effect strength of the service characteristics of self-service restaurants on the paths to the attractions of self-service restaurants. In terms of effect coefficients, the groups with certain and uncertain consumption intentions both believe that the service characteristics of self-service restaurants will not significantly affect the attractions of self-service restaurants.

(4) The two groups have no significant difference $(t=-0.515)$ in $(\mathrm{H} 4)$ the effect strength of the service characteristics of self-service restaurants on the paths to the consumers' perceived values. In terms of effect coefficients, the groups with certain and uncertain consumption intentions both believe that the service characteristics of self-service restaurants will not significantly affect the consumers' perceived values.

(5) The two groups have no significant difference $(t=1.558)$ in (H5) the effect strength of the consumers' technology involvement on the paths to the attractions of self-service restaurants. In terms of effect coefficients, the groups with certain and uncertain consumption intentions both believe that the consumers' technology involvement will significantly and highly affect the attractions of self-service restaurants.

(6) The two groups have significant difference $(t=2.266)$ in $(\mathrm{H} 6)$ the effect strength of the consumers' technology involvement on the paths to the consumers' perceived values. By comparing the effect coefficients, the group with uncertain consumption intentions has higher effects which are positive on this path than the group with certain consumption intentions, indicating that the group with certain consumption intentions will improve the feelings to perceived values even more due to the consumers' technology involvement.

(7) The two groups have significant difference ( $\mathrm{t}=-2.046)$ in (H7) the effect strength of the attractions of self-service restaurants on the paths to the consumers' perceived values. By comparing the effect coefficients, the group with certain consumption intentions has higher effects which are positive on this path than the group with uncertain consumption intentions, indicating that the group with certain consumption intentions will greatly improve the perceived values even more due to the attractions of self-service restaurants.

(8) The two groups have no significant difference $(t=0.511)$ in (H8) the effect strength of the attractions of self-service restaurants on the paths to the consumers' consumption willingness. In terms of effect coefficients, the groups with certain and uncertain consumption intentions both believe that the attractions of self-service restaurants will significantly and highly affect the consumers' consumption willingness.

(9) The two groups have significant difference (t=-1.933) in (H9) the effect strength of the consumers' perceived values on the paths to the consumers' consumption willingness. By comparing the effect coefficients, the group with certain consumption intentions has higher effects which are positive on this path than the group with uncertain 
consumption intentions, indicating that the group with certain consumption intentions will greatly improve the consumption willingness due to the consumers' perceived values.

In conclusion, the groups with certain and uncertain consumption intentions have 3 significant differences on the paths to all dimensions, indicating that the relationship strength of the groups with certain and uncertain consumption intentions on part of the paths is significantly different. Hence, the hypothesis H10 is partially supported, showing that different consumption willingness really does cause the difference in relationship structure, which is an important finding of this study (see Table 2).

Table 2. Comparative analysis of the multi-group competing model

\begin{tabular}{|c|c|c|c|}
\hline \multirow{3}{*}{ Hypotheses } & \multicolumn{2}{|c|}{$\begin{array}{l}\text { Evaluation value of } \\
\text { standard parameters }\end{array}$} & \multirow{3}{*}{$T$ test } \\
\hline & $\begin{array}{l}\text { Certain } \\
\text { consumptio } \\
\mathrm{n} \text { intentions }\end{array}$ & $\begin{array}{l}\text { Uncertain } \\
\text { consumptio } \\
\text { n intentions }\end{array}$ & \\
\hline & $\mathrm{n}=498$ & $\mathrm{n}=152$ & \\
\hline $\begin{array}{l}\text { H1: "Experience connotation" to self-service restaurants would have } \\
\text { significant positive influence on the "attractions" }\end{array}$ & $0.27 * * *$ & $0.21 * *$ & -0.381 \\
\hline $\begin{array}{l}\text { H2:"Experience connotation" to self-service restaurants would have } \\
\text { significant positive influence on consumers' "perceived values" }\end{array}$ & $0.139 * * *$ & $0.249 * * *$ & 1.649 \\
\hline $\begin{array}{l}\text { H3:"Service characteristics" of self-service restaurants would have } \\
\text { significant positive influence on the "attractions" }\end{array}$ & -0.065 & 0.031 & 1.151 \\
\hline $\begin{array}{l}\text { H4:"Service characteristics" of self-service restaurants would have } \\
\text { significant positive influence on consumers" "perceived values" }\end{array}$ & 0.02 & -0.009 & -0.515 \\
\hline $\begin{array}{l}\text { H5: Consumers" "technology involvement" would have significant } \\
\text { positive influence on "attractions" of self-service restaurants }\end{array}$ & $0.615 * * *$ & $0.709 * * *$ & 1.558 \\
\hline $\begin{array}{l}\text { H6: Consumers" "technology involvement" would have significant } \\
\text { positive influence on consumers" "perceived values" }\end{array}$ & -0.033 & $0.231 * *$ & $2.266^{* *}$ \\
\hline $\begin{array}{l}\text { H7: "Attractions" of self-service restaurants would have significant } \\
\text { positive influence on consumers' "perceived values" }\end{array}$ & $0.685 * * *$ & $\mathbf{0 . 4 0 3} * * *$ & $-2.046 * *$ \\
\hline $\begin{array}{l}\text { H8:"Attractions" of self-service restaurants would have significant } \\
\text { positive influence on consumption willingness }\end{array}$ & $0.78 * * *$ & $0.844 * * *$ & 0.511 \\
\hline $\begin{array}{l}\text { H9: Consumers' "perceived values" of self-service restaurants would } \\
\text { have significant positive influence on consumption willingness }\end{array}$ & $0.161 * * *$ & 0.066 & $-1.933 *$ \\
\hline
\end{tabular}

H10: Groups with different consumption willingness are significantly differentiated in the path strength of relationship models partially supported of self-service restaurants

\begin{tabular}{ccccccccccc}
\hline \multicolumn{1}{l}{ Indicators of Model Adaptability } \\
\hline \multicolumn{1}{c}{$\boldsymbol{x}^{\mathbf{2}}$} & d.f. & P value & $\boldsymbol{x}^{\mathbf{2}} /$ d.f. & RMR & GFI & AGFI & NFI & RFI & CFI & RMSEA \\
\hline 2106.355 & 1382 & .000 & 1.524 & .063 & .867 & .842 & .873 & .857 & .952 & .028 \\
\hline$*: \mathrm{P}<0.1, * *: \mathrm{P}<0.05, * * *: \mathrm{P}<0.01$ & & & & & & & & \\
\hline
\end{tabular}

\section{Conclusion and Suggestions}

\subsection{Research Conclusion}

This study took the consumers who had eating-out experience as the study subjects to discuss the effects of the experience connotation to self-service restaurants, service characteristics and consumers' technology involvement on the attractions of self-service restaurants, consumers' perceived values and consumers' consumption willingness, to 
establish the relationship models and to compare the difference of groups with different consumption willingness. The study results are as follows:

(1) The experience connotation to self-service restaurants has significantly positive effects on the attractions of self-service restaurants, and this result is the same with the viewpoints presented by Bake \& Crompton (2000); Fennell (2002), indicating that the consumers' experience with some products or consumption situations given by self-service restaurants will improve the restaurants' attractions.

(2) The experience connotation to self-service restaurants has significantly positive effects on the consumers' perceived values, and this result is the same with the viewpoints presented by Norris (1941); Monroe (1990); Holbrook (1999), Schmitt (2000); Pine \& Gilmore et al. (2003). Hence, once being stimulated by experience, the consumers will generate individual's subjective perceived values in their minds to judge the commodity or service quality.

(3) The service characteristics of self-service restaurants have no significant effect on the attractions of self-service restaurants, and this result is inconsistent with the study hypothesis, indicating that the self-service model in self-service restaurants may enable the consumers to spend more time and energy to understand, compared with most of the current consumption models equipped with service staff. Therefore, the service characteristics of self-service restaurants will not improve the attractions.

(4) The service characteristics of self-service restaurants have no significant effect on the consumers' perceived values, and this result is inconsistent with the study hypothesis, indicating that the customers may generate perceived values based on the service quality of the service staff. The feelings of perceived values will not be improved for no staff will provide services in self-service restaurants.

(5) The consumers' technology involvement has significantly positive effects on the attractions of self-service restaurants, and this result is the same with the viewpoints presented by McIntyre (1989); McIntyre \& Pigram (1992); Kyle \& Mowen (2005), indicating that, for self-service restaurants, the cognitions on the attractions of restaurants will be produced due to high technology involvement of consumers.

(6) The technology involvement of the group with certain consumption intentions has no significant effect on the consumers' perceived values, and the technology involvement of the group with uncertain consumption intentions will significantly improve the feelings of perceived values. Hence, the group with uncertain consumption intentions will improve the value perception to the self-service restaurants due to high technology involvement.

(7) The attractions of self-service restaurants have significantly positive effects on the consumers' perceived values, and this result is the same with the viewpoints presented by Bolton \& Drew (1991), Motherbaugh \& Beatty (2000), and Lovelock et al. (2001). If feeling the attractions of self-service restaurants, the customers will form their value cognitions, such as themes, facilities and services of the restaurants. If the consumers are made to feel attracted, the consumers' perceived values and the consumption behavior intentions will be improved, especially for the group with certain consumption intentions.

(8) The attractions of self-service restaurants have significantly positive effects on the consumers' consumption willingness, and this result is the same with the viewpoints presented by Leiper (1990), Peter \& Weiermair (2000). For example, regarding the self-service restaurants, the customers will feel the attractions and generate the consumption willingness due to innovative services and unique facilities. Furthermore, as the attractions increase, the customers' willingness will be improved, which is the optimal index to predict the future consumption of the customers.

(9) The group with certain consumption intentions will greatly improve the consumption willingness due to value cognitions, and the group with uncertain consumption intentions will not improve the consumption willingness despite of value cognitions. Hence, the perceived values of the group with certain consumption intentions have highly positive effects on its consumption willingness.

\subsection{Managerial Implications}

This study discussed the effects of the experience connotation to self-service restaurants, service characteristics and consumers' technology involvement on the attractions of self-service restaurants, consumers' perceived values and consumers' consumption willingness. Based on the empirical analysis, this study established the relationship models of all dimensions and the efficient measurement variables, which can provide important study tools and relevant concepts to the academic circle and the industrial circle with academic value and practical value.

By comparing 3 independent variables, it is found from the study results that, for those who eat out, the experience 
connotation will have positive effects on the attractions and the perceived values, the consumers' technology involvement has significantly positive effect on the attractions of self-service restaurants, the attractions of self-service restaurants have significantly positive effects on the consumers' perceived values, and the attractions of self-service restaurants and the consumers' perceived values have significantly positive effects on the consumption willingness.

As a result, the self-service restaurants containing the 2 factors of experience connotation and technology involvement will enable the consumers to produce the positive attraction to the self-service restaurants. Accordingly, in promotion of self-service, the restaurant operators can design situations in various styles and technological operation modes to attract the consumers to gain more novel experience, in order to improve the attractions of self-service restaurants. For instance, in self-service restaurants, the food delivery service offered by robots enables the consumers to automatically order dinners and settle accounts. Technological innovation and unique facilities are used to enable the consumers to experience the modern technology, to be fascinated and to improve the values, and then produce the consumption willingness.

On the contrary, the service characteristics of self-service restaurants will not improve the attractions and perceived values of self-service restaurants. Therefore, it is suggested that, when developing self-service restaurants, the restaurant operators can import the semi-self-service mode to enable the consumers to gradually accept the technological product and the semi-self-service and thus to produce the positive perceived values, then they can further accept the self-service operation mode.

\subsection{Research Limitations and Suggestions}

Many factors affect the consumers going to self-service restaurants, wherein, this study only discussed the experience connotation service characteristics and technology involvement. In the future study, more variables will be added in to perfect the relationship models. Moreover, the consumers referred in this study are Taiwanese, but in the future, the in-depth study will be conducted for the consumers of other nationalities to discuss the difference in consumption of people from other cultures. In addition, the association models established in this study can also be applied in other kinds of catering industry, which can make the conceptual framework of the study more universal and increase the value of study.

\section{References}

Addis, M., \& Holbrook, M. B. (2001). On the conceptual link between mass customization and experiential consumption: An explosion of subjectivity. Journal of Consumer Behavior, 1(1), 50-66. https://doi.org/10.1002/cb.53

Ajzen, I. (1991). The theory of planned behavior. Organizational Behavior and Human Decision Processes, 50, 179-211. https://doi.org/10.1016/0749-5978(91)90020-T

Albrecht, K. (1992). Only thing that matters. Executive Excellence, 9, 7-7.

Arnould, E., Price, L., \& Zinkhan, G. (2004). Consumers (2nd ed.). Boston: McGraw-Hill / Irwin.

Baker, D. A., \& Crompton, J. L. (2000). Quality, satisfaction and behavioral intentions. Annals of Tourism Research, 27(3), 785-804. https://doi.org/10.1016/S0160-7383(99)00108-5

Belanche, D., Flavián, C., \& Alfredo, P.R. (2016). Understanding interactive online advertising: Congruence and product involvement in highly and lowly arousing, skippable video ads. Journal of Interactive Marketing, 37, 75-88. https://doi.org/10.1016/j.intmar.2016.06.004

Birkinshaw, J. (2000). Entrepreneurship in the Global Firm: Enterprise and Renewal. U.S: Sage.

Blackwell, R. D., Miniard, P.W., \& Engel, J. F. (2001). Consumer Behavior (10th eds.). NY: The Dryden Press.

Bruce, L. A., \& Abhijit, B. (2002). The effects of discount level, price consciousness and sale proneness on consumers' price perception and behavioral intentions. Journal of Business Research, 55, 575-583.

Carmines, E. G., \& McIver, J. P. (1981). Analyzing models with unobserved variables: Analysis of covariance structures. In G. W. Bohrnstedt, \& E. F. Borgatta (Eds.), Social Measurement (pp. 65-115). Beverly Hills, Calif: Sage.

Chiu, C. M., Hsu, M. H., \& Wang, E. T. (2006). Understanding knowledge sharing in virtual communities: An integration of social capital and social cognitive theories. Decision Support Systems, 42(3), 1872-1888. https://doi.org/10.1016/j.dss.2006.04.001 
Cronin, J. J. Jr., \& Taylor, S. A. (1992). Measuring service quality: A reexamination and extension. Journal of Marketing, 56(3), 55-68. https://doi.org/10.1177/002224299205600304

Cronin, J. J., Brady, M. K., \& Hult, T. G. (2000). Assessing the effects of quality, value, and customer satisfaction on consumer behavioral intentions in service environments. Journal of Retailing, 76(2), 193-218. https://doi.org/10.1016/S0022-4359(00)00028-2

Davis, F. D. (1989). Perceived usefulness, perceived ease of use, and user acceptance of information technology. MIS Quarterly, 13(3), 319-340. https://doi.org/10.2307/249008

Davis, F. D., Bagozzi, R. P., \& Warshaw, P. R. (1989). User acceptance of computer technology: A comparison of two theoretical models. Management Science, 35, 982-1003. https://doi.org/10.1287/mnsc.35.8.982

Den Hertog, P., \& Bilderbeek, R. (1999). Conceptualizing service innovation and service innovation patterns. Research Programme on Innovation in Services (SIID) for the Ministry of Economic Affairs, Dialogic, Utrecht.

Dodds, W. B., Monroe, K. B., \& Grewal, D. (1991). Effects of price, brand, and store information on buyers' product evaluations. Journal of Marketing Research, 28(3), 307-319.

Evans, J. R., \& Laskin, R. L. (1994). The relationship marketing process: A conceptualization and application. Industrial Marketing Management, 23(5), 439-452. https://doi.org/10.1016/0019-8501(94)90007-8

Fennell, D. A. (2002). Ecotourism Programme Planning. Cabi. https://doi.org/10.1079/9780851996103.0000

Fishbein, M., \& Ajzen, I. (1975). Belief, Attitude, Intention and Behavior: An Introduction to Theory and Research. Addison-Wesley, Reading, MA.

Fornell, C. R., \& Larcker, F. F. (1981). Structural equation models with unobservable variables and measurement error. Journal of Marketing Research, 18, 39-51. https://doi.org/10.1177/002224378101800104

Gefen, D. (2000). E-commerce: the role of familiarity and trust. Omega, 28(6), $725-737$. https://doi.org/10.1016/S0305-0483(00)00021-9

Getz, D. (1991). Festival, Special Events, and Tourism. NY: Van No strand Reinhold.

Gibson, H. J. (2005). Understanding sport tourism experiences. In J. Higham (Ed.), Sport Tourism Destinations. Burlington, MA: Elsevier Butterworth-Heinemann. https://doi.org/10.1016/B978-0-7506-5937-6.50012-2

Gronroos, C. (1984). A Service Quality Model and Marketing Implications. European Journal of Marketing, 18(4), 36-44. https://doi.org/10.1108/EUM0000000004784

Gunn, C. A., \& Var, T. (2002). Tourism Planning: Basics, Concepts, Cases. Psychology Press.

Hanna, N., \& Wozniak, R. (2001). Consumer Behavior an Applied Approach. NJ: Prentice-Hall, Inc.

Heskett, J. L., Jones, T. O., Loveman, G. W., Sasser, W. E., Jr., \& Schlesinger, L. A. (1994). Putting the service-profit chain to work. Harvard Business Review, 72(2), 164-174.

Holbrook, M. B. (1999). Consumer Value: A Framework for Analysis and Research. Psychology Press. https://doi.org/10.4324/9780203010679

Holbrook, M. B., \& Hirschman, E. C. (1982). The Experiential Aspects of Consumption: Consumer Fantasies, Feelings, and Fun. The Journal of Consumer Research, 9(2), 132-140. https://doi.org/10.1086/208906

Hozak, K. (2012). Managerial guidance for applying RFID in the tourism industry. Interdisciplinary Journal of Contemporary Research in Business, 4(2), 18-30.

Hulten, A. (2011). Sensory Marketing: The Multi-Sensory Brand-Experience Concept. European Business Review, 23(3), 256-273. https://doi.org/10.1108/09555341111130245

Jayawardhena, C., Souchon, A. L., Farrell, A. M., \& Glanville, K. (2007). Outcomes of service encounter quality in a business-to-business context. Industrial Marketing Management, 36(5), 575-588. https://doi.org/10.1016/j.indmarman.2006.02.012

Jones, M. A., Mothersbaugh, D. L., \& Beatty, S. E. (2000). Switching barriers and repurchase intentions in services. Journal of Retailing, 76(2), 259-274. https://doi.org/10.1016/S0022-4359(00)00024-5

Joreskog, K. G., \& Sorbom, D. (1989). LISREL 7 User's Reference Guide. Chicago: Scientific Software Inc.

Kay, M. J. (1993). Making mass customization happen: Lessons for implementation. Planning Review, 21(4), 14-18. https://doi.org/10.1108/eb054421 
Kerlinger, F. N. (1978). Foundation of Behavioral Research. NY: McGraw-Hill.

Kwun, J. W., \& Oh, H. (2004). Effects of brand, price, and risk on customers' value perceptions and behavioral intentions in the restaurant industry. Journal of Hospitality \& Leisure Marketing, 11(1), 31-49. https://doi.org/10.1300/J150v11n01_03

Kyle, G. T., Graefe, A. R., Manning, R., \& Bacon, J. (2003). An examination of the Relationship between leisure activity involvement and place attachment among hikers along the Appalachian Trail. Journal of Leisure Research, 35(3), 249-273. https://doi.org/10.1080/00222216.2003.11949993

Kyle, G., \& Mowen, A. J. (2005). An examination of the leisure involvement-agency commitment relationship. Journal of Leisure Research, 37(3), 342-363. https://doi.org/10.1080/00222216.2005.11950057

Kyle, G., Bricker, K., Graefe, A., \& Wickham, T. (2004). An examination of recreationists' relationships with activities and settings. Leisure Sciences, 26(2), 123-142. https://doi.org/10.1080/01490400490432019

Laurent, G., \& Kapferer, J. N. (1985). Measuring Consumer Involvement Profiles. Journal of Marketing Research, 2(22), 41-53. https://doi.org/10.1177/002224378502200104

Lee, J., \& Allway, A. (2002). Effects of Personal Control on Adoption of Self-service Technology Innovations. Journal of Services Marketing, 16(6), 553-572. https://doi.org/10.1108/08876040210443418

Lehtinen, U., \& Lehtinen, J. R. (1982). Service Quality: A study of quality dimensions. Service Management Institute.

Leiper, N. (1990). Tourism Planning-An Integrated and Sustainable Development. NY: Van Nostrand Reinhold.

Leiper, N. (1990). Tourist attraction systems. Annals of Tourism Research, 17(3), 367-384. https://doi.org/10.1016/0160-7383(90)90004-B

Lovelock, C. H. (2001). Services Marketing (4th ed.). Prentice Hall International.

Lovelock, C. H., \& Young, R. F. (1979). Look to consumers to increase productivity. Harvard Business Review, 57(3), 168-178.

McIntyre, N. (1989). Recreation involvement: The personal meaning of participation. University of New England.

McIntyre, N., \& Pigram, J. J. (1992). Recreation specialization reexamined: The case of vehicle-based campers. Leisure Sciences, 14(1), 3-15. https://doi.org/10.1080/01490409209513153

Monroe, K. B. (1990). Pricing: Making Profitable Decisions. NY: Mc Graw-Hill Book Company.

Morwitz, V. G., \& Schmittlein, D. (1992). Using segmentation to improve sales forecasts based on purchase intent: Which "intenders" actually buy?. Journal of Marketing Research, 29(4), 391-405.

Parasuraman, A., Zeithaml, V. A., \& Berry, L. L. (1985). A conceptual model of service quality and its implications for future research. The Journal of Marketing, 41-50. https://doi.org/10.1177/002224298504900403

Petrick, J. F. (2004). The roles of quality, value and satisfaction in predicting cruise passengers' behavioral intentions. Journal of Travel Research, 42(4), 397-407. https://doi.org/10.1177/0047287504263037

Pine, B. J., \& Gilmore, J. H. (1998). Welcome to the experience Economy. Harvard Business Review, 76(4), 97-107.

Rao, A. R., \& Monroe, K. B. (1989). The effect of price, brand name, and store name on buyers' perceptions of product quality: An integrative review. Journal of Marketing Research, 351-357.

Ryu, K., Han, H., \& Jang, S. (2010). Relationships among hedonic and utilitarian values, satisfaction and behavioral intentions in the fast-casual restaurant industry. International Journal of Contemporary Hospitality Management, 22(3), 416-432. https://doi.org/10.1108/09596111011035981

Saleh, F., \& Ryan, C. (1993). Jazz and knitwear: Factors that attract tourists to festivals. Tourism Management, 14(4), 289-297. https://doi.org/10.1016/0261-5177(93)90063-Q

Schiffman, L. G., \& Kanuk, L. L. (2000). Consumer Behavior (7th ed.), pp. 15-36. NY: Prentice Hall.

Schmitt, B. H. (1999). Experiential marketing. Journal of Marketing Management, 15(3), 53-67. https://doi.org/10.1362/026725799784870496

Schmitt, B. H. (2000). Experiential Marketing: How to get customers to sense, feel, think, act, and relate to your company and brands. NY: The Free Press.

Sheth, J. N., Newman, B. I., \& Gross, B. L. (1991). Why we buy what we buy: A theory of consumption values. 
Journal of Business Research, 22(2), 159-170. https://doi.org/10.1016/0148-2963(91)90050-8

Sproles, G. B. (1985). Behavioral science theories of fashion. The Psychology of Fashion, 55-70.

Tam, J. L. M. (2000). The effects of service quality, perceived value and customer satisfaction on behavioral intentions. Journal of Hospitality and Leisure Marketing, 6(4), 31-43.

Wang, Y., Po Lo, H., Chi, R., \& Yang, Y. (2004). An integrated framework for customer value and customer-relationship-management performance: a customer-based perspective from China. Managing Service Quality: An International Journal, 14(2/3), 169-182. https://doi.org/10.1108/09604520410528590

Weiermair, K., \& Peters, M. (2000). Tourist attractions and attracted tourists: how to satisfy today's' fickle' tourist clientele?. Journal of Tourism Studies, 11(1), 22.

Woodruff, R. B. (1997). Customer value: the next source for competitive advantage. Journal of the Academy of Marketing Science, 25(2), 139-153. https://doi.org/10.1007/BF02894350

Zeithaml, V. A. (1988). Consumer perceptions of price, quality and value: A means-end model and synthesis of evidence. Journal of Marketing, 52(3), 2-22. https://doi.org/10.1177/002224298805200302

Zeithaml, V. A., \& Bitner, M. J. (1996). Service Marketing (International Editions). Singapore: Mc Graw-Hill. 